Magne Dypedahl

Associate Professor at the Faculty of Business, Languages and Social

Sciences, Østfold University College

Jutta Eschenbach

Associate Professor at the Faculty of Business, Languages and Social

Sciences, Østfold University College

\title{
Introducing Intercultural Learning in a New Nordic Master’s Program
}

\begin{abstract}
This article presents the rationale behind a 10 ECTS course in "Intercultural learning" which is an integral part of a new master's program for teachers of English and German at Østfold University College: "Fremmedspråk i skolen". We present the content and organization of the course. Furthermore, we reflect on the students' own intercultural learning by analyzing two types of data: the students' comments on the course blog and their final reflection notes. Finally, we discuss the students' learning in the light of their ability to relate to various concepts of culture.

The theoretical discussion of the concepts of culture is based on literature on two different approaches to culture, namely more simplistic and essentialist ideas of nationality and ethnicity on the one hand and more theoretically founded ideas of cultural complexity on the other.

We found many good reasons for choosing an eclectic approach to language didactics which combines old and new approaches to the concept of culture. With regard to the students' own intercultural learning, it is difficult to find an unequivocal answer to the question of how much they learned. What we can say is that the students show many signs of improved intercultural competence. Moreover, almost all the teachers among these students claim that they make use of their intercultural knowledge in the classroom by combining their language teaching with more intercultural learning than before.
\end{abstract}

\section{Introduction}

Against the backdrop of increasing internationalization, intercultural competence is considered one of the key qualifications of the $21^{\text {st }}$ century. Especially foreign language teachers are important in this regard (Lundgren, 2002; Sercu et al., 2005). The aim of developing intercultural competence is also stated in the Common European Framework of Reference for Languages (CEFR) and the national curriculum for Knowledge Promotion (Council of Europe, 2001; Utdanningsdirektoratet, 2006a, 2006b, 2006c, 2010). In order to 
encourage more focus on intercultural competence in foreign language teaching, a course in "Intercultural learning" was made an integral part of a new master's program for teachers of English and German at Østfold University College in Norway: "Fremmedspråk i skolen".

This article describes this 10 ECTS course and how we assess student learning as it manifests itself in the course work of the first group of master's students who were enrolled in the fall of 2009. First we will present the rationale behind the course, its content and its organization. Then we assess whether two of the aims of the course were fulfilled, namely that students should improve their own intercultural competence and learn how to promote intercultural learning in the classroom.

\section{Intercultural learning in the National Curriculum for Knowledge Promotion}

The term "intercultural learning" is used here to refer to the pedagogical process of developing intercultural competence. Intercultural competence can be defined as the "ability to ensure a shared understanding by people of different social identities, and [the] ability to interact with people as complex human beings with multiple identities and their own individuality" (Byram et al., 2002, p. 10).

According to Michael Byram, intercultural competence consists of three particular competences: knowledge, skills and attitude. These competences are closely interconnected and further complemented by the component critical cultural awareness. Attitude relates to openness, respect, tolerance, feelings, curiosity and readiness to look at things from different perspectives. Knowledge relates to both culture-general knowledge, such as knowledge about processes that might come into play when individuals with different social identities interact, and culture-specific knowledge, such as about one's own cultural contexts or the cultural contexts of others. Skills relates to the ability to analyze cultures, acquire new knowledge about other cultures and to master intercultural encounters in practice. Critical cultural awareness refers to being critical towards one's own and other people's values.

Primary and secondary educators need to play a key role in enabling their students to develop these various aspects of intercultural competence (e.g. Göbel, 2009, p. 179; Bertelsmann Stiftung, 2008). However, many foreign language teachers find it very difficult to define or even relate to the concept of intercultural competence. One reason is that the subject curricula and program subjects for English and foreign languages in Norway are vague when it comes to how intercultural competence can actually be developed. Indeed, in the subject curriculum and the program subjects for English the concept of intercultural competence is not even used (Utdanningsdirektoratet, 2006a, 2010). It is used in the subject curriculum or program subjects for foreign 
languages, but here it is neither defined nor explained (Utdanningsdirektoratet, 2006b, 2006c).

This does not mean, however, that the national curriculum does not have intercultural learning as an aim. Even the previous national curricula, Reform 94 and Reform 97, suggested that teachers should have an intercultural perspective on foreign language teaching (cf. Simensen, 2003; Dypedahl, 2007). The same approach to language teaching is also evident in the Common European Framework of Reference for Languages: Learning, Teaching, Assessment (Council of Europe, 2001, pp. 103-106). In accordance with this there are passages which clearly can be understood as a call for more intercultural learning in the present subject curricula and program subjects for English and foreign languages. For instance, in the subject curriculum for foreign languages, intercultural competence is mentioned as one of the prerequisites for "successful communication and participation in many areas" (Utdanningsdirektoratet, 2006b, p. 1). In the subject curriculum for English as well as the subject curriculum for foreign languages it is also stated that the subjects will contribute "insight into the way others live and their views on life, values and cultures" (Utdanningsdirektoratet, 2010, p. 1; 2006b, p. 1).

Furthermore, in the program subject "International English" two of the competence aims are to enable the pupils ${ }^{1}$ to "use language appropriate to the situation in social, professional and intercultural contexts" and to "reflect on how cultural differences and dissimilar value systems can affect communication" (Utdanningsdirektoratet, 2006a, p. 4). In the program subject "Foreign language II" one of the competence aims is to enable the pupils to "elaborate on and discuss how knowledge of languages and cultural insight can promote multicultural cooperation and understanding” (Utdanningsdirektoratet, 2006c, p. 4). Moreover, in the program subject "Foreign language III" two of the aims are to enable the pupils to "discuss their own opinions about social and cultural similarities, as well as dissimilarities that could prove an obstacle to understanding, respect and communication with the culture of the target language area" and to "discuss the multicultural circumstances in the target language area, reflect on cultural differences and show empathy in their encounters with other cultures" (Utdanningsdirektoratet, 2006c, p. 5).

These aims do not make it easier to relate to intercultural competence. The main challenge is the very concept of culture itself. Many definitions of this concept tend to refer to culture as a complex system of world views, beliefs, and values shared by a group of people, which is very much in line with the traditions within the field of North American anthropology (Altmayer, 2009, p. 125). This approach to culture can also be seen in the national curriculum, for instance when it is stated that learning another language also means gaining insight into the way others live and their views on life values and cultures. However, in the curriculum the word "culture" is also used in such a broad sense 
that studying culture can easily be interpreted almost exclusively as traditional civilization studies or "Landeskunde".

In any case, the concept of culture seems to be interpreted as a fairly simplistic one. As Karen Risager writes, we have "the more simplistic and essentialist ideas of nationality and ethnicity" on the one hand, and "the more theoretically founded ideas of cultural complexity" on the other (Risager, 2009, p. 23). Among other things, simplistic and essentialist ideas of nationality mean that a traditional relationship between language and homogenous national culture is assumed. This concept of culture is still dominant in foreign language teaching, as is evident in the contrastive and nation-oriented approach in the national curriculum. However, culture is increasingly viewed as a social construction and as a complex and dynamic concept which is linked to the concept of identity (Hu, 1995; Kramsch, 1998a). Ideally, foreign language teaching should follow in the same path.

Still, how teachers interpret the intercultural aspects of the national curriculum will most definitely depend on their knowledge of intercultural learning and the concept of culture. Although the curriculum gives some leads with regard to the intercultural dimension of language teaching, both the concept of intercultural competence and the concept of culture remain diffuse and difficult to grasp. There are, of course, many teachers who are well acquainted with the field of intercultural communication or social anthropology. This can be a good starting point for the development of intercultural didactics within foreign language teaching. At the same time, it can be claimed that there has been very little focus on the intercultural dimension of language teaching in teacher education.

\section{The philosophy of the course}

Any course is based on implicit philosophies and traditions within a certain field of study, but there are also conscious choices which need to be made. One of the decisions we made was to enable our students to relate to both concepts of culture mentioned above. Second, we wanted to introduce our students to the long tradition of teaching intercultural communication in other fields than education. This meant that we sought to bring together the understanding of intercultural competence in the discourse of education with the understanding of intercultural competence in business and other types of discourse, as exemplified by scholars such as Geert Hofstede, Fons Trompenaars and Edward T. Hall (cf. Hofstede \& Hofstede, 2005; Trompenaars \& Hampden-Turner, 1997; Hall, 1959, 1966, 1976).

Third, we wanted to create a plurilingual learning environment by letting the master's students of English (approximately 20) and German (approximately 10) work partly together. Since the master's program is organized in cooperation 
with two universities in Sweden, Linnaeus University in Växjö and the University of Gothenburg, there would also be at least two mother tongues involved.

Fourth, we wanted to move beyond teaching various theories of intercultural learning. We also aimed at improving the master's students' own intercultural competence. One approach to this was to make use of the students' different cultural backgrounds as an asset in the teaching of intercultural competence. In this context cultural background refers to such factors as age, gender, education and nationality. With regard to nationality, it turned out that there was quite a range of birthplaces among the students: Sweden, Norway, Germany, Slovakia, Portugal and Spain. Moreover, there were two Norwegian students who lived in the United States and Singapore, respectively.

\section{The content of the course}

The course consisted of three main units, and in the first unit we focused on basic concepts of intercultural communication. The field of intercultural communication can be described as the study of factors which may influence communication between people of different social identities. It is a fairly recent phenomenon that topics within the field of intercultural communication are included in foreign language teaching in Norway and Sweden. Since we considered this knowledge to be the very basis of intercultural competence, however, we wanted to make the discussion of classical theories within the field of intercultural communication one of the main components of our course. These theories include different approaches to concepts such as ethnocentrism, stereotypes, prejudice, racism, identity, verbal communication, non-verbal communication (e.g. gestures, silence and eye contact), time, face, power, world view and values.

We invited the students to participate in a critical discussion of the theories of Geert Hofstede, Fons Trompenaars and Edward T. Hall. In particular we encouraged the students to be critical when it came to the static and descriptive nature of some of these theories. As an alternative we introduced the students to more dynamic models of communication, such as social constructivist theory and hermeneutics (cf. Dahl, 2006).

In the second unit of the course we focused on intercultural communication in the field of foreign language education. Our starting point was the question of how intercultural learning is dealt with in education policy. To answer this question the students were asked to analyze official documents such as the Common European Framework of Reference for Languages and the most relevant national curricula for English and foreign languages in Norway and Sweden (Council of Europe, 2001; Utdanningsdirektoratet, 2010, 2006a, 2006b, 2006c). 
Our aim was also to give the master's students an understanding of why and how intercultural competence has become a key element in foreign language teaching. For this purpose we looked at how culture has been dealt with in foreign language education over the years. Here the students were introduced to different approaches to culture studies in foreign language teaching (Risager, 1998, 2007).

Our main focus in this unit was the concept of "intercultural competence" itself (Byram, 1997; Knapp-Potthoff, 1997). How can intercultural learning be integrated in foreign language education in general? Here we included a discussion of the intercultural speaker as a new model for foreign language teaching, as opposed to the native speaker (Kramsch, 1998b). We also discussed the teacher's own intercultural competence as a prerequisite for promoting intercultural learning in the classroom (Risager, 2000; Dypedahl, 2007).

The third unit in the course was more practical in its approach to intercultural learning. The students were presented with possible intercultural learning tasks in foreign language teaching (Grau \& Würffel, 2003). They were asked to read about various other projects in order to form their own ideas about intercultural learning (e.g. Byram \& Cain, 1998; Morgan, 2001). They were introduced to ethnography, rich points and discourse analysis as possible methodological tools for approaching intercultural learning. Furthermore, we discussed the challenge of evaluating intercultural competence, both in general and in class (Byram, 1997, 2009; Hu, 2008; Lund, 2008).

The main task of this unit, and the final assignment of the course as such, was a project in which the students were required to combine the theory they had studied with practice. They could focus on intercultural learning in the classroom, the teacher's own intercultural competence or the pupils' intercultural competence in primary or secondary school. Some examples of intercultural learning in the classroom were intercultural learning through film (movies, TV-series, commercials), books (fictional and non-fictional) and through the Internet. The students could also write about how intercultural competence training can be combined with more "traditional" civilization studies or language training in general. With regard to the teacher's own competence, the students could focus on how teachers view the intercultural aspect of foreign language teaching. When it comes to developing the pupils' intercultural competence, the master's students could discuss various methods for changing pupils' attitudes to other cultures.

\section{The organization of the course}

The course was organized to comprise one face-to-face meeting in Halden, Norway, along with regular online communication. When it comes to online communication tools, we used both synchronous and asynchronous teaching and 
learning. For synchronous teaching and learning we used the online communication tool Elluminate (www.elluminate.com). It provides a virtual classroom, and we gathered up to 10-15 students for weekly sessions. In the German class Elluminate was used both for lecturing and discussions, whereas it was used mainly for discussions in the English class. First of all, Elluminate provides a channel for dialogue, in addition to such technical teaching tools as a whiteboard, sharing of web pages and a chat box. There is also a camera function, but we did not use this due to a higher risk of technical problems.

For the asynchronous teaching and learning we used a blog (http://interkulturellkompetanse.wordpress.com/) to discuss the theory of the course. The blog was only open to invited members in order to protect the privacy of people who might be identified when the students shared personal intercultural experiences. The blogs were organized according to the topics discussed each week. The students of English and German, respectively, had separate threads in the blog, but they could freely read and take part in all the discussions.

Most importantly, we found that the blog gave rise to different types of discussion than the synchronous communication. The students could refer to theories in a more elaborate way since they had time to think about what they were going to write. They also had far more choices regarding points of departure for discussions or what discussions to follow up on. Compared to synchronous meetings, this could make it more difficult to follow one thread in the discussions, but it could also make it more exciting.

More than anything else, the blogs reflected the huge individual differences between the students when it came to interests, knowledge and culture. Regardless of all the individual differences, however, the discussion points encouraged the students to reflect on their own culture and adapt the theory in question to their own teaching situation. The purpose was two-fold in the sense that we also wanted the students to improve their own intercultural competence.

We learned one important lesson with regard to blogs. Despite many lively discussions in which the students applied theory to their own experiences, the discussions had a tendency to stop without teacher participation. Since most of the students worked alone, feedback from the teachers was crucial, especially when it came to discussing or reconstructing theory. Indeed, many students said explicitly that they wanted and needed feedback.

\section{Assessing intercultural learning in the course: Materials and methods}

The overall goals of the course were, as mentioned, to improve the students' own intercultural competence and to give them new ideas about intercultural learning in the classroom. Accordingly, after the course was completed we 
looked for indications of improved intercultural competence on the part of the students and progress regarding how they related to intercultural learning in the classroom. To this end we analyzed two types of data: the students' comments on the blog and their final reflection notes.

As was also mentioned above, the blog was used to discuss both the theoretical and practical aspects of the course. Most of the tasks offered to the students were intended to help the students reconstruct various theories and discuss them. To encourage further intercultural learning they were also asked to reflect on their own culture, share their views on intercultural communication and look at the teacher's role in light of intercultural communication and culture pedagogy. In the final reflection notes the students evaluated their own intercultural learning. They were asked to assess both the development of their own intercultural competence and what impact the course might have on their own teaching. Obviously, there is reason to be critical here. Since the final reflection notes were mandatory, there is always the possibility that students assess the development of their intercultural competence in a way they think is favorable to their own coursework.

In our assessment of the students' own intercultural learning, we focus on three aspects. First, we will discuss whether the students base their discussions on a simplistic or a more complex concept of culture when dealing with intercultural topics, both in terms of personal learning and in the context of teaching. Since students need to understand the concept of culture before they can fully understand the concept of intercultural competence, this aspect is vital.

Second, we will look at the extent to which the students themselves think they have improved their own intercultural competence. We base this discussion on the criteria of Michael Byram's theory of intercultural competence, which primarily is developed for foreign language teaching (Byram, 1997, see above).

Third, we will discuss how the students view the possibilities of introducing more intercultural learning in the classroom. In our opinion, the intercultural dimension of language teaching needs to be given more attention, and it is interesting to see what new ideas for intercultural learning the students share with us and fellow students.

The goal of our assessment is not to evaluate the students, but rather to illustrate the learning process. Therefore we use qualitative methods when analyzing the students' blog and reflection notes. More specifically, the perspective of our analysis is based on constructivism. This means that we do not regard knowledge as absolute truths about the world, but rather as constructions influenced by factors such as perspectives and interests. The focus is on how meaning is constructed by the individual. The starting point for our analysis of the data is to "encircle" the phenomena we have chosen to focus on and then re-construct how the students seem to establish their perspective of intercultural learning (cf. Løngreen, 2006). 


\section{The students' concept of culture}

On the one hand, the blog discussions reveal a certain fascination with the theories of Hofstede, Trompenaars and Hall. On the other hand, the students are soundly skeptical of the static nature of these theories and conclude that these descriptive theories can easily lead to stereotyping. They also point out that many of these theories do not sufficiently take into account the heterogeneous nature of all cultures:

I liked Hofstede's book. It was interesting to read and included many illustrative examples. What I do not like is the fact that Hofstede does not say anything about differences within a nation. Nations are described as homogenous entities. But they are not. In my opinion, this can cause general prejudice.

(Student of German, B2-O) ${ }^{2}$

On the one hand, I find it very interesting and challenging to read about Hofstede's theories and value dimensions. [...] On the other hand, I also find it disturbing the way he categorizes every nation. He holds a pessimistic view of the cultural values of the different countries and there seems to be no way of escaping the fixed patterns. Isn't categorizing of cultures in a way contributing to the very same prejudices that should be avoided?

(Student of English, B2-T)

It is also very interesting to see how students move from a fairly homogeneous and simplistic view of culture to a more heterogeneous and complex one when they are asked to use theory to reflect on their own culture. Typically, a comparison of national cultures can be quite homogenous to begin with. In the following example a Belgian student, who has lived in Norway for many years, starts a discussion on uncertainty avoidance and leaving babies alone in their prams in public places:

Another thing which struck me here in Norway is how laidback mothers are about letting their (very) small kids run around without paying attention to them. [...] When my children were babies I used to take them with me inside the shop when I was doing errands. This is not common practice in Norway [...]. I'd rather run the risk of being considered a hysterical mother than exposing my child being patted on by any passersby or having his pram occupied by a stray dog or cat, or worse: become another victim of traffic hazards or pedophilia [...]

(Student of English, B2-T)

This comment and a similar comment from a Spanish student lead to a number of comments which bring individual behavior into the discussion. Here is one example of a comment from a Norwegian student: 
Despite my efforts to become more laidback and let my kids explore the world, I would never ever leave them outside any shop, and I cannot believe this is common practice in Norway.

(Student of English, B2-I)

As a result, the contradicting experiences lead to a more dynamic and heterogeneous view of Norwegian culture. This is revealed when the Belgian student adds a new comment:

I read that several of you would never leave your babies outside a shop. Maybe times have changed. [...] Some students have discussed how the oil adventure has changed Norway, and I have the definite impression that Norway has changed a lot since I first arrived here in 1980. Back then it seemed like paradise [...]

(Student of English, B2-T)

Here the student realizes that national cultures are heterogeneous and changeable. Ideally, such a realization should lead to a discussion of how we should relate to national cultures in class, and this issue was raised by the students of German:

Nevertheless, in the Swedish curricula the word compare is still used. But if we do not share the assumption of national homogenous cultures, the following question arises: "What should we compare to in our foreign language teaching?"

(Student of German, B4-D)

What I'm personally puzzled about is the emphasis on avoiding generalizations because there are no homogenous cultures and culture expresses itself uniquely in each individual. [...] What are we supposed to convey to the students?

(Student of German, B7-H)

The same student who asks the last question above also suggests an answer, namely that the language learners should be made aware of how diverse all countries are:

We can let students understand that there is so much diversity in any country that it is impossible for the teacher to say something about the German culture which is an ultimate truth. We should teach them that there are no right or wrong answers, but simply a number of possibilities and combinations. In this way they may become more tolerant when they one day meet a German who does not correspond to their expectations at all.

(Student of German, B7-H)

With regard to the concept of culture, our reconstruction of the students' own learning processes shows how the students move from a rather simplistic nationoriented concept of culture to a more complex one. It also shows how they face 
the problem of handling these two very different concepts of culture in their own teaching situation.

\section{The students’ own intercultural competence}

In the final reflections the students were asked to write about the extent to which they thought they had improved their own intercultural competence during the semester. This type of self-assessment is not easy, but it is evident that the course had been an eye-opener for many students with regard to intercultural issues in general:

The word intercultural, which was not an active word in my vocabulary before August, now pops up everywhere. [...] For me the word has not just expanded my vocabulary, but also opened my eyes.

(Student of German, RA1-B)

Although I have lived as a foreigner in Norway for years, I have never consciously thought about the importance of intercultural learning and intercultural communication in this way.

(Student of German, RA2-O)

Students also indicate in the final reflections that the course really has made a difference in their lives. Indeed, one student even describes it as an inner journey towards more self-awareness:

The course "intercultural learning" has been a kind of inner journey. [...] This has been the most personal subject, where the aspect of awareness has played a major role.

(Student of English, RB1-S)

What is also evident is that the terminology and various theoretical concepts introduced in this course have given the students new tools for analyzing and expressing things they previously had been unaware of:

What I found to be most useful was to become familiar with terminology and concepts which could put words to my thoughts. [...] That's why I found this course so interesting - because I was given "a new tool” [...]

(Student of English, RB10-M)

In general, the students express that they have learned a lot about their own cultural background and how culture may affect communication. There are many examples of increased self-awareness, not least on the part of the students who have lived in several national cultures. However, in the comment below we are reminded that intercultural competence is no self-evident consequence of having lived abroad: 
I started the course with the attitude that I was an interculturally well-developed human being because I have lived in different countries and have known different cultures, but I have learned a lot more than that. I had realized that people to some extent have different values, but not until now have I understood why this is so.

(Student of German, RB14-E)

According to Byram (1997), intercultural competence is of course not only about knowledge and awareness, but also about attitude (see above). When it comes to this particular competence, the students underline that they have changed their attitudes as a result of more knowledge and self-awareness, not least with regard to ethnocentrism. Many students also claim that they have changed their attitudes by developing more tolerance, acceptance and respect for cultural diversity:

Through this course I have realized that I too often have used my own culture as the yardstick when judging other cultures [...]

(Student of German, RB-O)

I have started to think back on my travelling days in remote countries in South America. I almost feel ashamed of my irritation as a backpacker when I had to wait and wait, and things took time. I was not used to their attitudes towards time, but I soon learned that this was different in South America. But now I have gained more tolerance and acceptance of this.

(Student of English, RB8-R)

Obviously, it is difficult to evaluate the extent to which students really have changed their attitudes. What we can conclude is that many students claim to be more open and tolerant when it comes to other people's values and behavior. At the same time many students also view this relativistic approach with critical eyes and conclude that everything should not be tolerated or accepted. There is a call for universal criteria for evaluating practice:

We should have the right to react to things which we find morally unacceptable, without being called ethnocentric. In my opinion, the Universal Declaration of Human Rights should be the common standard for the whole world.

(Student of German, B2-D)

I completely understand your call for simplicity as to ethics and cultural understanding, [...] But - ethics and intercultural issues are not simple. Especially in classes with students of multicultural backgrounds. But also culturally homogenous pupils (whatever that is) sometimes reveal opinions that are non-mainstream, or even unacceptable (like racism, for example). If you only raise questions, you open for cultural and ethical relativism; "anything goes". It certainly complicates the discussion and your position as an educator, doesn't it? You don't want to put your student in a situation where s/he might lose face, and at the same time you feel the responsibility of expressing disagreement. I find it very difficult [...]

(Student of English, B6-S) 
Based on the materials used for this assessment, it can be concluded that the majority of students have developed both cultural-general and culture-specific knowledge. In analyzing and interpreting intercultural encounters, the students show the ability to apply this knowledge. They also seem to have developed the ability to relativize their own values and behavior, at the same time as they show the ability to critically evaluate both their own values and other people's values. In other words, they show that they have critical cultural awareness, which according to Byram's theory is necessary for an interculturally competent person.

Obviously, we can never know for certain that the students improved their ability to master intercultural encounters in practice. What we do know, however, is that most of them improved their intercultural knowledge. This could to a large extent be tested at the oral exam at the end of the course. As far as intercultural skills and attitude are concerned, we can make assumptions based on the self-assessment of the students, but that is as far as it goes. The challenges of evaluating intercultural competence, which were intensively discussed in the course, were thus mirrored in practice as well.

\section{Intercultural learning in the classroom}

As stated earlier, one of the main aims of the course was to make the students able to teach intercultural competence in the classroom. We found that the intercultural dimension of both language teaching and teaching in general was somewhat of a revelation to many students:

I think I have missed out on many good occasions to address intercultural issues in my English classes, simply because I have probably not been aware of the scope of intercultural learning and thus not been able to discover the potential.

(Student of English, RC2-C)

The teacher is a role model. How then do we improve our own intercultural competence, and how do we help young people becoming competent in that field? These thoughts are rather new for me, since the focus earlier has been on learning facts, not on developing attitudes. I have definitely acquired a new awareness of how important it is to provide young people with the necessary tools to develop tolerance and intercultural competence. Only then can they become citizens of the world who feel comfortable with their own identity and culture while being able to interact with other cultures with openness and respect. A teacher can actually contribute to the building and keeping up of democratic ideals, a very noble task indeed!

(Student of English, RC3-T)

Although many students still feel uncertain when it comes to the practical aspects of teaching intercultural competence, they write that they now consider 
intercultural learning to be an important and integral part of teaching. Their new awareness of interculturality has given them a basis on which they can build their teaching in the future. They also see the possibility of introducing new activities in the classroom and using the teaching materials from an intercultural perspective:

At this point I am sure we all are more aware of different possibilities for designing activities which create curiosity and openness toward other cultures with different values. We now have a platform to build on for further teaching which will lead to well-prepared and designed learning processes for our students in order to improve intercultural competence.

(Student of English, RC7-A)

On the other hand, there are students who for various reasons are skeptical when it comes to certain aspects of intercultural learning. The main reason for this is the difficulty of evaluating intercultural competence:

I think a lot about how I provide for intercultural learning in my teaching. It is not difficult to come up with ideas. The problem lies elsewhere: The relevant aspects of the European Common Framework of Reference and the National Curriculum have no influence on the formal assessment, namely the national exam. If I spend a lot of time in class comparing cultures, discussing stereotypes and prejudice, it will not contribute to a better result in the written exam. Most of the emphasis in the exam is on written competence, and most of all linguistic aspects. Content plays second fiddle, whether we like it or not. With regard to summative assessment in class, I will of course have to take the aims in the curriculum into account, but how do I assess intercultural competence?

(Student of German, RF2-Q)

In conclusion, the students agree that intercultural learning should be an integral part of foreign language teaching. At the same time they are skeptical when it comes to useful criteria for evaluating pupils' intercultural competence. The students of German tend to see more challenges than the students of English regarding intercultural learning in the classroom. Some of them find it difficult to teach intercultural competence due to pupils’ poor linguistic skills. However, all the students, irrespective of language, state that they find knowledge of the intercultural aspect of teaching to be very useful and rewarding.

\section{Discussion}

One of the most interesting findings in our assessment of the course is the ability of the students to relate to various concepts of culture and the signs they show of improved intercultural competence. As noted in the discussion of the national curriculum above, a simplistic and essentialist concept of culture is dominant in 
foreign language education. This approach to culture is supported both by teaching material and most teacher education programs at college or university level. Indeed, the whole idea of studying national cultures along with languages can be looked upon as an essentialist approach to culture. Within this tradition of language teaching it is assumed that cultures which are classified as more or less homogeneous and static entities can be described objectively (e.g. Hu, 1995; Dahl, 2006; Risager, 2009).

Moreover, research shows that interlocutors use what we refer to here as an essentialist concept of culture when they construct their identities. This is especially true when individuals define their social roles in contexts where people from different countries communicate (e.g. Hu, 1995; Keim, 2002; Eschenbach, 2004). In political discourse leaders use what we could classify as an essentialist concept of culture in speeches to appeal to people's loyalty, patriotism and sense of unity based on national values (Beasley, 2001, p. 33).

The essentialist approach to culture is also the initial perspective of the students in their discussions. Moving beyond this perspective can be difficult. So far the challenge has been that the essentialist approach, which is widely used, does not adequately describe modern societies, whereas the more adequate complex concept of culture has been used mostly for theoretical purposes up until recently (cf. Risager, 2009, p. 15). It is claimed that nobody has succeeded in using the more complex theories as a basic approach to foreign language teaching. According to Altmeyer, we do not yet have a satisfactory answer to the question of how this might be done (Altmeyer, 2009, p. 124).

One suggestion, however, is to use a philosophical hermeneutic framework to provide the principles for intercultural learning in foreign language teaching, or at least for intercultural learning. Hermeneutics can be described as the theory and practice of interpretation and understanding. Based on a moderate theory of hermeneutics influenced by the German philosopher Hans-Georg Gadamer, we define intercultural hermeneutics as an interest in the dynamics of how a common understanding can be established between people of different social identities (cf. Nynäs, 2006, p. 26).

In fact, the essentialist interpretation and the hermeneutic interpretation have many things in common, for instance that cultures represent continuity and that they influence our understanding of the world and ourselves. In other words, there is no disagreement when it comes to the belief that the world cannot be observed from a neutral point of view. From an essentialist approach to culture, however, culture is closely linked to human behaviour, whereas a hermeneutical approach to culture means that culture is regarded as a context in which we interpret and understand the world.

It is the relationship between culture and the individual that changes in a comparison between an essentialist concept of culture and a more dynamic approach to culture. By focusing on culture as context, language teachers can work with the history and national culture of another country as relevant 
knowledge about contexts which can be relevant for understanding other human beings, but it should not be translated into knowledge about other people's individual identities. As Peter Nynäs writes, "[c]ulture does not explain human behaviour" (Nynäs, 2006, p. 25). The problem is that the essentialist concept of culture is often used to explain why people behave the way they do. One example of this is Geert Hofstede's famous value dimensions (Hofstede \& Hofstede, 2005).

In intercultural hermeneutics, on the other hand, the focus is on the dynamic aspects of communication. The hermeneutic circle can illustrate that in the process of interpretation of a text or human interaction we move back and forth between the individual parts and the whole. The focus of the hermeneutic circle is the fusion of horizons. The interpreter brings his or her background to the situation, and this constitutes his or her horizon. The interaction with other people is then described as a fusion of horizons. Gadamer also uses the term "prejudice" to describe what we bring with us when we read a text or interact with other people. Importantly, Gadamer's use of the word "prejudice" is not intended to carry negative connotations, but simply refers to our preunderstanding (Gadamer, 1990, p. 276).

Regardless of the philosophical underpinnings of our course, the students seem to have no problems accepting a more dynamic and complex concept of culture once they have been introduced to it and reflected on it in discussions with other students. They may also intuitively understand that culture is a very complex concept once they start discussing differences between people who come from the same national culture. The next step is to integrate this approach to culture in foreign language teaching. A source of inspiration here are a number of empirical research projects that have been conducted recently to find out more about the process of cultural learning in light of this more complex concept of culture (e.g. Altmayer, 2009; Lundgren, 2009a).

\section{Conclusion}

In our opinion, an interculturally competent teacher is a sine qua non when implementing intercultural learning in foreign language classes. The purpose of this article has been to describe a new course in "Intercultural learning" and to assess the course by looking at the teacher training students' own intercultural learning process. Generally, it is difficult to find an unequivocal answer to the question of how much students have learned (cf. Lundgren, 2009b). Since intercultural learning is a life-long learning process and involves attitudes, an assessment of intercultural learning is particularly difficult. What we can conclude is that the discussions on the blog and the reflection notes give evidence of intercultural learning. 
With regard to the various competences involved in intercultural learning, we find that the students have increased their culture-general knowledge in particular. They have also changed their view of culture from a simplistic concept of culture to a more complex one. When they discuss their own culture and other cultures, they prove able to use concepts of intercultural communication in their analysis. It is more difficult to decide whether they have developed more openness and respect, but students show how they have changed perspectives on many issues.

We believe that knowledge of intercultural communication for people with normal social skills inevitably leads to more intercultural competence, but intercultural competence is not sufficient in itself. Teachers also need methods for promoting intercultural learning. In our course many ideas were shared between students and instructors, and there is a wealth of good ideas to be found in various articles and teaching materials. Nonetheless, the course could only serve to set the process in motion. There is simply not time enough in a 10 ECTS course to go into depth when it comes to teaching methods.

We can also conclude that one challenge for language teachers is to develop a dynamic approach to culture in light of, or in spite of, a national curriculum which unintentionally may encourage a very simplistic approach to culture and communication. Another challenge is that overarching or systematic methods of developing intercultural competence in the classroom hardly exist yet. On the other hand, these challenges will also make it all the more interesting to work with intercultural learning in the years to come.

\section{References}

Altmayer, C. (2009). Instrumente für die empirische Erforschung kultureller Lernprozesse im Kontext von Deutsch als Fremdsprache. In A. Hu \& M. Byram (Eds.), Interkulturelle Kompetenz und fremdsprachliches Lernen: Modelle, Empirie, Evaluation - Intercultural competence and foreign language learning: Models, empiricism, assessment (pp. 123138). Tübingen: Gunter Narr Verlag.

Beasley, V. B. (2001). Identity, Democracy, and Presidential Rhetoric. In R. P. Hart \& B. H. Sparrow (Eds.), Politics, Discourse, and American Society. New Agendas (pp. 19-34). Lanham, Maryland: Rowman \& Littlefield Publishers, Inc.

Bertelsmann Stiftung and Fondazione Cariplo. (2008). Intercultural Competence - The key competence in the $21^{\text {st }}$ century? Retrieved from http://www.bertelsmannstiftung.de/bst/de/media/xcms_bst_dms_30238_30239_2.pdf .

Byram, M. (1997). Teaching and Assessing Intercultural Communicative Competence. Clevedon: Multilingual Matters.

Byram, M. (2009). Evaluation and/or Assessment of Intercultural Competence. In A. Hu \& M. Byram (Eds.), Interkulturelle Kompetenz und fremdsprachliches Lernen: Modelle, Empirie, Evaluation - Intercultural competence and foreign language learning: Models, empiricism, assessment (pp. 215-234). Tübingen: Gunter Narr Verlag. 
Byram, M., \& Cain, A. (1998). Civilisation / Cultural Studies: An Experiment in French and English Schools. In M. Byram \& M. Fleming (Eds.), Language Learning in Intercultural Perspective. Approaches through drama and ethnography (pp. 32-44). Cambridge: Cambridge University Press.

Byram, M., Gribkova, B., \& Starkey, H. (2002). Developing the Intercultural Dimension in Language Teaching. A Practical Introduction for Teachers. Strasbourg: Council of Europe. Retrieved from http://www.coe.int/t/dg4/linguistic/Source/Guide_dimintercult_EN.pdf

Council of Europe. (2001). Common European Framework of Reference for Languages: Learning, Teaching, Assessment. Strasbourg: Council of Europe. Retrieved from http://www.coe.int/T/DG4/Linguistic/Source/Framework_EN.pdf

Dahl, Ø. (2006). Bridges of Understanding. Perspectives on Intercultural Communication. In $\varnothing$. Dahl \& I. Jensen \& P. Nynäs (Eds.), Bridges of Understanding. Perspectives on Intercultural Communication (pp. 7-22). Oslo: Unipub forlag/Oslo Academic Press.

Dypedahl, M. (2007). Interkulturell kompetanse og kravet til språklæreren. Fokus på språk, 2, Halden: Fremmedspråksenteret. Retrieved from http://www.hiof.no/neted/upload/attachment/site/group55/Fokus_online_2_2007.pdf

Eschenbach, J. (2004). „,norwegische demokratie die funktioniert so“ - Zur kommunikativen Konstruktion von nationalkultureller Zugehörigkeit in einer deutsch-norwegischen Verhandlung. In E. L. Björk \& S. Vesterhus (Eds.). Kommunikasjon (pp. 41-59). Halden: Høgskolen i Østfold.

Gadamer, H. G. (1990). Wahrheit und Methode. Grundzüge einer philosophischen Hermeneutik (6th ed.). Tübingen: Mohr.

Göbel, K. (2009). Die Bedeutung von Kulturkontakterfahrungen der Lehrenden für die Grau, M., \& Würffel, N. (2003). Übungen zur interkulturellen Kommunikation. In K. R. Bausch \& H. Christ \& H. J. Krumm (Eds.), Handbuch Fremdsprachenunterricht (pp. 312-314). Tübingen, Basel: A. Francke Verlag.

Hall, E. T. (1959). The Silent Language. New York: Anchor Books.

Hall, E. T. (1966). The Hidden Dimension. New York: Anchor Books.

Hall, E. T. (1976). Beyond Culture. New York: Anchor Books.

Hofstede, G., \& Hofstede, G. J. (2005). Cultures and Organizations. Software of the Mind ( $2^{\text {nd }}$ ed.rev.). New York: McGraw-Hill.

$\mathrm{Hu}, \mathrm{A}$. (1995). Ist 'Kultur' eine fruchtbare, notwendige oder verzichtbare fremdsprachendidaktische Kategorie? Überlegungen aufgrund einer personenorientierten qualitativ-empirischen Studie. In L. Bredella, L. \& H. Christ (Eds.), Didaktik des Fremdverstehens (pp. 20-35). Tübingen: Gunter Narr Verlag.

Hu, A. (2008). Interkulturelle Kompetenz. Ansätze zur Dimensionierung und Evaluation einer Schlüsselkompetenz fremdsprachlichen Lernens. In V. Frederking (Ed.), Schwer messbare Kompetenzen. Herausforderungen für die empirische Fachdidaktik (pp. 11-35). Baltmannsweiler: Schneider Verlag Hohengehren.

Keim, I. (2002). Die Verwendung ethnischer Stereotypen im interethnischen Erstkontakt: Zum Zusammenhang von Selbst- und Fremddarstellung, Interaktionsmodalität und Perspektivität. In H. Kotthoff (Ed.), Kultur(en) im Gespräch (pp. 245-274). Tübingen: Gunter Narr Verlag.

Knapp-Potthoff, A. (1997). Interkulturelle Kommunikationsfähigkeit als Lernziel. In A. Knapp-Potthoff \& M. Liedke (Eds.), Aspekte interkultureller Kommunikationsfähigkeit (pp. 181-205). München: Iudicium Verlag.

Kramsch, C. (1998a). Language and Culture. Oxford: Oxford University Press. 
Kramsch, C. (1998b). The Privilege of the Intercultural Speaker. In M. Byram \& M. Fleming (Eds.), Language Learning in Intercultural Perspective. Approaches through drama and ethnography (pp. 26-31). Cambridge: Cambridge University Press.

Lund, R. (2008). Intercultural Competence - An Aim for the Teaching of English in Norway? Acta Didactica Norge, 2, (1). Retrieved from http://adno.no/index.php/adno/article/view/58/94

Lundgren, U, (2002). Interkulturell förståelse i engelskundervisning - en möjlighet. Malmö: Malmöhögskola. Retrieved from http://www.lub.lu.se/luft/diss/soc_400/soc_400.pdf

Lundgren, U. (2009a). Transatlantiskt samtal om skönlitterära texter - ett didaktiskt exempel. In L. Kåreland (Ed.), Läsa bör man ... ? - den skönlitterära texten i skola och lärarutbildning (pp. 168-191). Stockholm: Liber.

Lundgren, U. (2009b). Intercultural Teacher - A Case Study of a Course. In M. Byram, A. Feng \& M. Fleming (Eds.), Becoming Interculturally Competent through Education and Training. Clevedon: Multilingual Matters.

Løngreen, H. (2006). Method and Intercultural Communication Studies. In Ø. Dahl, I. Jensen \&P. Nynäs (Eds.), Bridges of Understanding. Perspectives on Intercultural Communication (pp.115-127). Oslo: Unipub forlag.

Morgan, C. (2001). The International Partnership Project. In M. Byram \& A. Nichols \& D. Stevens (Eds.), Developing Intercultural Competence in Practice (11-28). Clevedon: Multilingual Matters.

Nynäs, P. (2006). Interpretive Models of Estrangement and Identificiation. In Ø. Dahl \& I. Jensen \& P. Nynäs (Eds.), Bridges of Understanding. Perspectives on Intercultural Communication (pp. 23-37). Oslo: Unipub forlag / Oslo Academic Press.

Risager, K. (1998). Language Teaching and the Process of European Integration. In M. Byram \& M. Fleming (Eds.), Language Learning in Intercultural Perspective. Approaches through drama and ethnography (pp. 242-254). Cambridge: Cambridge University Press.

Risager, K. (2000). Lærerens interkulturelle kompetence. Sprogforum, 18, 14-20.

Risager, K. (2007). Language and Culture Pedagogy. From a National to a Transnational Paradigm. Clevedon: Multilingual Matters.

Risager, K. (2009). Intercultural Competence in the Cultural Flow. In A. Hu \& M. Byram (Eds.), Interkulturelle Kompetenz und fremdsprachliches Lernen: Modelle, Empirie, Evaluation - Intercultural competence and foreign language learning: Models, empiricism, assessment (pp. 15-30). Tübingen: Gunter Narr Verlag.

Sercu, L., Bandura, E., Castro, P., Davcheva, L., Laskaridou, C., Lundgren, U., Mendez Garcia, M., \& Ryan, P. (2005). Foreign Language Teachers and Intercultural Competence. An International Investigation. Clevedon: Multilingual Matters.

Simensen, Aud Marit (2003). Interkulturell kompetanse: Hvordan skal det forstås? Er det en målsetting spesielt for fremmedspråkene? In Språk og språkundervisning, 2, 5-9. Landslaget for moderne språk - Norge.

Trompenaars, F., \& Hampden-Turner, C. (1997). Riding the waves of culture: understanding cultural diversity in business ( $2^{\text {nd }}$ ed.). London: Nicholas Brealey.

Utdanningsdirektoratet. (2006a). English - Programme Subject in Programmes for Specialization in General Studies. Retrieved from http://www.udir.no/Stottemeny/English/Curriculum-in-English/_english/Programmes-forgeneral-studies/

Utdanningsdirektoratet. (2006b). Subject Curriculum for Foreign Languages. Retrieved from http://www.udir.no/Stottemeny/English/Curriculum-in-English/_english/Common-coresubjects-in-primary-and-secondary-education/ 
Utdanningsdirektoratet. (2006c). Foreign Languages - Programme Subject in Programmes for Specialization in General Studies. Retrieved from

http://www.udir.no/Stottemeny/English/Curriculum-in-English/_english/Programmes-forgeneral-studies/

Utdanningsdirektoratet. (2010). English Subject Curriculum. Retrieved from http://www.udir.no/Stottemeny/English/Curriculum-in-English/_english/Common-coresubjects-in-primary-and-secondary-education/

\footnotetext{
${ }^{1}$ We refer to primary and secondary school students as "pupils" to distinguish more clearly in the text between these students and the master's students.

${ }^{2}$ The quotes which originally were not written in English have been translated into English. All texts have been slightly adapted to make them as fluent as possible.
} 